\title{
Issues And The Use Of Social Media In Reference Services By Academic Library Personnel In Nigeria
}

\author{
F. N. Okoroma \\ Kenneth Dike Library University of Ibadan, Nigeria.
}

\begin{abstract}
Social Media platforms have revolutionized the patterns libraries serve their clientele as well as augment reference services delivery. This study seeks to address the issues militating against the integration of social media in reference services and the level of use by academic library personnel in Nigeria. Questionnaire instrument was used for data collection. 100 copies of questionnaire were distributed to the librarians and other library personnel at the national seminar in 2015 held at Kogi State University, Nigeria. 62 copies were filled and returned, given a response rate of $62 \%$. The study found that academic libraries' personnel in Nigeria have embraced the regular use of social media, but their application of these media in reference services is quite low. The issues contending with the integration of social media in reference services by academic library personnel in Nigeria include lack of awareness and training on the application of social media to reference services, coupled with infrastructural and technological problems. The study advocated for awareness and training programmes on the use of social media within the academic community and provision of appropriate and adequate infrastructure in academic libraries.
\end{abstract}

Keywords: Social media, Reference services, Academic libraries, Nigeria, Information

\section{INTRODUCTION}

It is quite obvious that Information Communication Technology (ICT) is pushing very hard on all aspect of human endeavor; education, commerce, health, judiciary, transportation as well as information science profession. This constant pressure calls for a redefinition and reshuffling of libraries's daily activities and procedures in other to meet up with the changing technological trends and users' behavior. It is not enough to identify the tasks, reasons and the strategies used for the accomplishment of the professional duties, libraries' management and information professionals must equally come to terms with the target groups of users and their changing information seeking behavior in this global age where every human information need can be accessed at a speed light with little or no stress at the most reasonable cost. It behooves an information professional to realize the dynamism of the present environment, the era and the user groups that are being served and to synchronize, with adequate and appropriate innovation, in other to remain relevant. It is on this backdrop that proactive academic libraries and their personnel globally are providing automated systems, digitized library resources and further still an interactive platform for the users to interact and contribute to knowledge. This enhances the fulfillment of libraries basic mandate, which is to provide users with resources, services and facilities that facilitate teaching, learning and research. Reference service is an important aspect of academic libraries' responsibilities towards fulfilling their goal. Reference service provides a platform for interaction between the clienteles and library personnel which determines the future patronage of the library.

Some of the services offered by academic libraries include current awareness services, selective dissemination of information (SDI), monthly accession list, user education, inter 
library-loan, borrowing of library materials either on reciprocal basis or on contractual basis, access to catalogue, manual or computerized, inter-library loan services, Internet services, subject literature search, and reference services (Aina, 2008and Omeluzor, 2010). Chebe (2012) opined that reference and information service is an aspect of library services in which contact between the reader and library materials is established through staff assistance, matching the user with the library materials which could be print or electronic resources. Interestingly, these services can be facilitated and made possible remotely by the use of social media network platforms by the academic library personnel.

Social media has been defined by authors in various ways. According to Kaplan Andreas (2010) social media is "a group of Internet-based applications that build on the ideological and technological foundations of Web 2.0, and that allow the creation and exchange of usergenerated content." Social media are computer-mediated tools which allow people to create, share or exchange information, ideas, and pictures/videos in virtual communities and networks. "Social media has been broadly defined to refer to 'the many relatively inexpensive and widely accessible electronic tools that enable anyone to publish and access information, collaborate on a common effort, or build relationships'" Jump up (2013). Social media depend on mobile and web-based technologies to create highly interactive platforms through which individuals and communities share, co-create, discuss, and modify user-generated content. They introduce substantial and pervasive changes to communication between businesses, organizations, communities, and individuals which are the focus of the emerging field of techno self studies.

Internet users continue to spend more time with social media sites than any other type of site. The total time spent on social media in the U.S. across PC and mobile devices increased by 99 percent to 121 billion minutes in July 2012 compared to 66 billion minutes in July 2011 (Jump up 2011). This reinforces the need to maximally utilize social media platforms for user's services by academic libraries' personnel. Tang (2012) ascertained that the benefits of participating in social media have gone beyond simply social sharing to building reputation and bringing in career opportunities and monetary income. Many social media sites provide specific functionality to help users re-share content. For example, Twitter's retweet button, Pinterest pin or Tumblr's reblog function. Businesses may have a particular interest in viral marketing; nonprofit organisations and activists may have similar interests in virality.

Aichner (2015) ascertains that social media technologies take on many different forms such as blogs, business networks, enterprise social networks, forums, microblogs, photo sharing, products/services review, social bookmarking, social gaming, social networks, video sharing and virtual worlds. Popular among the social media are: Facebook, MySpace, Wikis, LinkedIn, Twitter, YouTube, Flickr, Whatsap and Library Thing.

Facebook is the most popular now because it is librarian- friendly, with many applications like JSTOR search, World Cat, and much more. With Facebook librarians can interact with users to know their information need. The Facebook page on the library's web site acts as a portal to the library. Academic libraries use Facebook to market the library and the services available with a library fan page. Libraries advertise opening hours, location, and other information. Libraries also create event invitations for programs as an additional forum to promote library activities, even a basic Facebook page can serve as a reminder to use the resources available at an academic library ((Chu andMeulemans, 2008 and Farkas, 2007a). In Academic institutions where the students are; libraries have taken advantage of MySpace site to post calendars, custom catalog search tools, and blog features to improve their presence. 
Blogs provide an avenue for librarians to periodically post messages; share information on a particular subject or issue, and allow users to contribute to content. They can write articles, news on topical issues and expect an instant reaction from their users. Boxen (2008) ascertains that Blogs are web pages that consist of user-supplied content in chronological order. Wikis is a free online encyclopedia that gives a background knowledge and definition of concepts. It offers a platform for users to access, edit and contribute to content. This is a collaborative web page for developing web content. Wikis are open web pages that allow approved users to add and alter a page's content (Boxen, 2008). Wikis allow for higher use, participation and collaborative activities. With wikis Academic libraries can create subject links to resources on a chosen topic or for a particular class, including information regarding relevant databases and search tips tailored to that subject (Kroski, 2007b).

On the other hand through LinkedIn Librarians can get patrons connected with specialists in their particular field of interest. Librarians can use this platform to render specialized services such as Strategic Dissemination of Information (SDI), While YouTube allows individuals and organizations to post original videos. The site also enables users to embed their videos unto other web sites,

Twitter is a micro blogging application, to keep staff and patrons updated on daily activities, like frequently updated collections. Users can utilize this platform to type in short messages or status update. Librarians can use this platform to give users firsthand information on the ongoing national elections. Users can send Instant Messages (IM), complaints, reshare content or ask questions on a particular issue and get a feedback on the spot using Twitter's retweet.

Furthermore, in institutions, events such as important highlights of inaugural lectures, conferences and workshops are disseminated via the YouTube. YouTube also allows individuals and organizations to post original videos and to embed their videos onto other web sites.

Additionally, Librarians and other library personnel can use Flickr to share and distribute new images of library collections. Cover page of new arrivals of both books and journals can be disseminated to users via Flickr. Flickr allows users to post photographs and to create discussion groups. While Flickr is known largely as a photo sharing web site, it also allows users to post videos. Academic librarians post photos of the library and its staff to provide a virtual tour of the library itself while simultaneously putting a human face to the building. Farkas (2007b) collaborate that "general search of Flickr reveals that most academic libraries use Flickr to post pictures of the library building and its staff". Academic libraries can also post material from special collections on a Flickr (Andrea, 2010). Library Thing as well serves as a tool that enriches the library OPAC. Once an account is created, a list of books with ISBNs is sent to Library Thing which sends back a piece of code which is pasted into the footer of the Library OPAC. Librarians can utilize this to send a list of current publications to users.

In addition to multimedia web sites, there are also social games that can be used in student outreach. Second Life is an online reality game that allows libraries to set up virtual libraries and to provide library services, particularly reference services. Academic librarian Brian Mathews (2007a, p. 10) states that: these digital libraries provide a 3-D environment with the potential to include video tutorials, audio players, subject guides, database and catalog searching, live assistance, instructional sessions, meeting areas, and other features.. 
Literature has shown that many academic librarians are advocating for the use of social Web platforms to reach out to their users (Farkas, 2007a, b; Mathews, 2006, 2007a; Milstein, 2009, Andrea, 2010). But there are still issues and uncertainty on the full integration of social media in reference services by academic libraries' personnel in Nigeria. Andrea (2010) reported the need for quantitative and qualitative research about the use of social networking tools within academic libraries.

Andrea and Holley, (2010) noted that there are several concerns about the use of social media. Such issues need to be considered by any academic library using social networking web sites or considering the implementation of social networking outreach programs. Andrea further ascertained that there are very few quantitative studies available about the broad effectiveness of the approach. This makes it extremely difficult to determine if the social networking efforts are worth librarian time in competition with other established outreach methods.

Another concern about social networking is low usage. Mathews, (2006) reported that from the messages sent to 1,500 undergraduate and graduate students on Facebook by an academic librarian, only 48 responded. Another study focusing on Wiki use in academic libraries found that six out of 21 libraries reported difficulties with low participation rates (Chu, 2009). Kim and Abbas (2010) ascertained that librarians were often more interested in the library's social media applications than students. Thus for social media usage in academic libraries to be sustained, both the librarians and the users must be adequately interested.

Another issue borders on the library personnel attitude to the use of social media. A lack of librarian support for social networking also risks uneven service levels and upgrading of the sites. Also if only selective liaisons are proactive in social networking to provide subject support, subject-based support may become unequal among disciplines. (Andrea, 2010).

The study conducted by Amina (2015) revealed that privacy concern is the major challenge librarians encounter in the use of social media for promoting library and information resources and services, other challenges are low level of technology penetration and network problem, lack of awareness, lack of funds.

From the ongoing, there are issues on the use of the media, and very few researches on the subject as it relates to Nigeria. Hence the need to identify the level of use, the problems encountered and solutions to enhance adequate integration of social media by academic libraries' personnel in Nigeria.

The general objective of this work is therefore to identify the issues and the use of social media in reference services by academic library personnel in Nigeria.

The specific objectives are to:

a. Identify the types of social media sites that are in use by academic libraries' personnel in Nigeria.

b. Find out reasons why academic library personnel visit the sites.

c. Ascertain the frequency of visit to the sites by academic libraries' personnel in Nigeria.

d. To determine the level of application of social media in reference service by libraries' personnel in academic libraries in Nigeria

e. Determine the issues in the use of the social media for reference service in academic libraries in Nigeria. 
f. Proffer solutions to enhance the use of social media for reference service in academic libraries in Nigeria

\section{RESEARCH METHOD}

Questionnaire instrument was used for data collection. Survey questionnaire was designed for librarians and library staff involved in reference services in academic libraries in Nigeria. Section A consists of the respondents Bio data. Section B identifies the types of social media that are in use in academic libraries in Nigeria by libraries' personnel. Whereas section $C$ highlights the frequency of use of the social media for reference services in academic libraries, Section D looks into the issues to the use of the social media in academic libraries in Nigeria, while Section E deals with suggestions on enhancing the use of social media for reference services in academic libraries in Nigeria. 100 copies of the questionnaire were distributed to libraries' personnel in Nigeria at the National seminar in 2011 held at Kogi State University, Nigeria. Simple frequencies and percentage were used in data analyses. 


\section{FINDINGS}

Table 4.1: Provides details of the institutions used for the study,

Table 4.1 Distribution of Respondents by Institutions

\begin{tabular}{|c|c|c|}
\hline Name of Institution & Frequency & Percentage \\
\hline UNICAL & 3 & $4.8 \%$ \\
\hline JABU & 2 & $3.2 \%$ \\
\hline MCPHERSON & 1 & $1.6 \%$ \\
\hline UNIJOS & 1 & $1.6 \%$ \\
\hline DELSU & 2 & $3.2 \%$ \\
\hline UNILAG & 7 & $11.3 \%$ \\
\hline FUNAAB & 3 & $4.8 \%$ \\
\hline AKWAPOLY & 1 & $1.6 \%$ \\
\hline OYSCAT & 1 & $1.6 \%$ \\
\hline FUTMINNA & 2 & $3.2 \%$ \\
\hline NIGER STATE & 1 & $1.6 \%$ \\
\hline UNIBEN & 1 & $1.6 \%$ \\
\hline ABIA STATE & 1 & $1.6 \%$ \\
\hline FED POLY ILARO & 2 & $3.2 \%$ \\
\hline FCE, OYO & 1 & $1.6 \%$ \\
\hline U.I & 9 & $14.5 \%$ \\
\hline LEAD CITY & 1 & $1.6 \%$ \\
\hline NATIONAL ASSLIB & 1 & $1.6 \%$ \\
\hline CODE OF CONDUCT LIB & 1 & $1.6 \%$ \\
\hline THE POLY IBADAN & 2 & $3.2 \%$ \\
\hline OYO STATE LIBRARY BOARD & 2 & $3.2 \%$ \\
\hline LAUTECH & 2 & $3.2 \%$ \\
\hline EACOED & 1 & $1.6 \%$ \\
\hline NISER LIB & 2 & $3.2 \%$ \\
\hline UNN & 2 & $3.2 \%$ \\
\hline KOGI STATE UNI & 3 & $4.8 \%$ \\
\hline OSUN STATE UNI & 1 & $1.6 \%$ \\
\hline THE SUN LIB & 1 & $1.6 \%$ \\
\hline AMERICAN UNIV. LIB. & 2 & $3.2 \%$ \\
\hline BABCOCK & 1 & $1.6 \%$ \\
\hline FUTO & 1 & $1.6 \%$ \\
\hline NIHORT & 1 & $1.6 \%$ \\
\hline TOTAL & 62 & $100 \%$ \\
\hline
\end{tabular}

Table 4.1 shows the distributions of respondents by institutions, 32 universities were represented in the study. Both Federal, state and private universities were well represented. Out of 100 questionnaire copies distributed to the librarians in the universities in Nigeria, 62 copies were filled and returned, given a response rate of $62 \%$. From the table the highest number of respondents came from University of Ibadan (UI) with $9(14.5 \%)$ respondents, seconded by University of Lagos (UNILAG) with 7(11.3) respondents, followed by University of Calaba (UniCal), Federal University of Abeokuta (FUNAAB) and Kogi State University has $3(4.8 \%)$ persons each. On the other hand Joseph Afe Babalola University (JABU), Delta State University (DELSU), Federal University of Mina (FUT MINNA), Federal Polytechnic Ilaro, Polytechnic Ibadan, Oyo State library Board, LAUTECH, American University Library that have 
2 persons each. While the rest of the universities have 1 representative each. In all Federal Universities had the highest representatives with 15 universities, followed by state, which has 11 universities that participated in the study and 6 universities from state.

Table 4.5: The use of social media by academic libraries' personnel in Nigeria.

\begin{tabular}{|l|l|l|l|}
\hline Question & Options & Frequency & Percentage \% \\
\hline \multirow{2}{*}{$\begin{array}{c}\text { Do you use Social } \\
\text { Networking Sites? }\end{array}$} & Yes & 54 & 87.1 \\
\cline { 2 - 4 } & No & 08 & $12.9 \%$ \\
\cline { 2 - 4 } & Total & $\mathbf{6 2}$ & $\mathbf{1 0 0}$ \\
\hline
\end{tabular}

The above table 4.5 reveals that many $54(87.1 \%)$ out of the 62 respondents were using social networking sites while only $08(12.9 \%)$ respondents were not. That means that social media usage in academic libraries in Nigeria is very high among libraries' personnel.

Table 4.6: Social media sites used by the academic library personnel

\begin{tabular}{|l|l|l|l|}
\hline Question & Network Sites & Frequency & Percentage \% \\
\hline \multirow{3}{*}{$\begin{array}{l}\text { Identify the Social } \\
\text { use. }\end{array}$} & FACEBOOK & 53 & $82.8 \%$ \\
\cline { 2 - 4 } & BLOGS & 17 & $26.6 \%$ \\
\cline { 2 - 4 } & LINKEDIN & 25 & $39.1 \%$ \\
\cline { 2 - 4 } & MY SPACE & 4 & $6.2 \%$ \\
\cline { 2 - 4 } & YOU TUBE & 23 & $35.9 \%$ \\
\cline { 2 - 4 } & FLICKER & 5 & $7.8 \%$ \\
\cline { 2 - 4 } & LIBRARY THING & 9 & $14.1 \%$ \\
\cline { 2 - 4 } & WHATSAPP & 30 & $46.9 \%$ \\
\cline { 2 - 4 } & TWITTER & 15 & $23.4 \%$ \\
\cline { 2 - 4 } & NONE & 5 & $7.8 \%$ \\
\hline
\end{tabular}

The above table 4.6 highlights the different social media platforms being used by the respondents. It reveals that $53(82.8 \%)$ respondents were using facebook, $17(26.6 \%)$ respondents were using blogs, 25(39.1\%) respondents were using linkedin, 04(6.2\%) respondents were using My Space, 23 (35.9\%) respondents were using You tube, 05 (7.8\%) respondents were using flicker, 09(14.1\%) respondents were using library thing, while $30(46.9 \%)$ respondents and $15(23.4 \%)$ others were using Whatsap and twitter respectively. Whereas 5(7.8\%) persons were not using social networking site at all. The table shows that majority of the respondents are quite familiar with and do make use of different kinds of social media but facebook is the most used site, seconded by Whatsap, then LinkedIn and blogs.

Table 4.7: The Reasons Behind respondents use of sites

\begin{tabular}{|l|l|l|l|}
\hline Question & Reasons & Frequency & Percentage \% \\
\hline \multirow{4}{*}{$\begin{array}{l}\text { What is the reason } \\
\text { behind your }\end{array}$} & Looks and layout & 14 & $21.9 \%$ \\
\cline { 2 - 4 } sites & Business Networking & 20 & 31.2 \\
\cline { 2 - 4 } & Job/Research & 30 & $46.9 \%$ \\
\cline { 2 - 4 } & Friends & 22 & $34.4 \%$ \\
\cline { 2 - 4 } & Blogging & 23 & $35.9 \%$ \\
\cline { 2 - 4 } & Security & 05 & $7.8 \%$ \\
\cline { 2 - 4 } & Games & 04 & $6.2 \%$ \\
\cline { 2 - 4 } & User - Friendly & 25 & $39.1 \%$ \\
\cline { 2 - 4 } & Communities & 09 & 29.1 \\
\hline & Chatting & 19 & \\
\hline & Total & & \\
\hline
\end{tabular}


The above table 4.7 shows the various reasons behind the respondent's use of the social media sites. 14(21.9\%) respondents used the sites for looks and layout, 20(31.2\%) respondents used them for business networking, 30(46.9\%) respondents used them for Job/Research, 23(36\%) respondents used them for blogging Whereas 05(7.8\%) respondents were using the sites for security, 04(6.2\%) respondents were using them for games, 25(39.1\%) respondents were using them for friendliness, 09(14.1\%) respondents were using them for communities and $19(29.7 \%)$ respondents were using them for chatting. This table reveals that less than half of librarians use the social media sites for research and job related activities.

Table 4.8 Frequency of Respondents visit to the Social Networking Sites

\begin{tabular}{|l|l|l|l|}
\hline Question & Options & Frequency & Percentage \% \\
\hline \multirow{2}{*}{$\begin{array}{l}\text { What is the } \\
\text { Frequency of your } \\
\text { visit to the Social } \\
\text { Networking Sites? }\end{array}$} & Everyday & 41 & $75.9 \%$ \\
\cline { 2 - 4 } & Twice a Week & 08 & $14.8 \%$ \\
\cline { 2 - 4 } & Once a Week & 04 & $7.4 \%$ \\
\cline { 2 - 4 } & Once a Month & 01 & $1.9 \%$ \\
\cline { 2 - 4 } & & & $\mathbf{1 0 0}$ \\
\cline { 2 - 4 } & Total & $\mathbf{5 4}$ & \multicolumn{2}{|}{} \\
\hline
\end{tabular}

The above table 4.8 shows that majority of the respondents visit social networking sites every day. 41(75.9\%) respondents were using the sites everyday, 08(14.8\%) respondents were using them twice a week, 04(7.4\%) respondents were using them once a week while 01(1.9\%) respondent was using them only once a month. It could be deduced that most of the respondents visit social media sites every day.

Table 4.2 Social Media used by academic libraries' personnel in Nigeria for reference services

\begin{tabular}{|l|l|l|l|}
\hline Question & Social Media & Frequency & Percentage \% \\
\hline \multirow{3}{*}{$\begin{array}{l}\text { Please, Identify the type } \\
\text { use in your media that you }\end{array}$} & FACEBOOK & 27 & $42.2 \%$ \\
\cline { 2 - 4 } services & BLOGS & 08 & $12.5 \%$ \\
\cline { 2 - 4 } & LINKEDIN & 09 & $14.1 \%$ \\
\cline { 2 - 4 } & MY SPACE & 02 & $3.1 \%$ \\
\cline { 2 - 4 } & YOU TUBE & 09 & $14.1 \%$ \\
\cline { 2 - 4 } & FLICKER & 04 & $6.2 \%$ \\
\cline { 2 - 4 } & LIBRARY THING & 09 & $14.1 \%$ \\
\cline { 2 - 4 } & WHATSAPP & 14 & $21.9 \%$ \\
\cline { 2 - 4 } & TWITTER & 06 & $31.4 \%$ \\
\cline { 2 - 4 } & NONE & 20 & $31.2 \%$ \\
\hline
\end{tabular}

The above table 4.2 shows the social media being used by the respondents for reference purposes. It reveals that $27(42.2 \%)$ respondents were using the face book for reference purpose frequently, 08(12.5\%) respondents were using blogs for the same purpose, 09(14.1\%) respondents were using LinkedIn for the same purpose, $02(3.1 \%)$ respondents were using my space for reference services. The table further reveals that $09(14.1 \%)$ respondents were using you tube for reference services, 04(6.2\%) respondents were using flicker for reference services, and $14(21.9 \%)$ were using twitter for such purpose. While $20(31.2 \%)$ persons were not using social media for reference services at all. Table 4.2 reveals that face book was the highest in usage by academic library personnel in Nigerian for reference services while MySpace is the least in use. 
Table 4. 3 The Frequency of Social Media use for Reference Services

\begin{tabular}{|l|l|l|l|}
\hline Question & Options & Frequency & Percentage \% \\
\hline \multirow{3}{*}{$\begin{array}{l}\text { What is the Frequency of Media for } \\
\text { Reference Services in }\end{array}$} & Everyday & 21 & $38.2 \%$ \\
\cline { 2 - 4 } your Library & Twice a Week & 09 & $16.4 \%$ \\
\cline { 2 - 4 } & Once a Week & 03 & $5.5 \%$ \\
\cline { 2 - 4 } & Once a Month & 03 & $5.5 \%$ \\
\cline { 2 - 4 } & None & 19 & $34.5 \%$ \\
\cline { 2 - 4 } & Total & $\mathbf{5 5}$ & $\mathbf{1 0 0}$ \\
\hline
\end{tabular}

The above table 4.3 shows the frequency of social media use in reference services. The table reveals that only $21(38.2 \%)$ respondents used the social media for reference services everyday, 09(16.4\%) respondent used the media for reference services twice a week and 03(5.5\%) respondents use the media for such purpose once a month while $19(34.5 \%)$ persons do not use social media at all for reference services. Table 4.3 affirms the low use of social media platforms for reference services in academic libraries in Nigeria.

Table 4.4: Level of Application of the Social Media for Reference Services

\begin{tabular}{|l|l|l|l|}
\hline Question & Options & Frequency & Percentage \% \\
\hline \multirow{3}{*}{$\begin{array}{l}\text { What is the Frequency of } \\
\text { Reference Services in }\end{array}$} & Low use & 18 & $38.3 \%$ \\
\cline { 2 - 4 } your Library & Moderate use & 13 & $27.7 \%$ \\
\cline { 2 - 4 } & High use & 10 & $21.3 \%$ \\
\cline { 2 - 4 } & None Use & 06 & $12.8 \%$ \\
\cline { 2 - 4 } & Total & $\mathbf{4 7}$ & $\mathbf{1 0 0}$ \\
\hline
\end{tabular}

The above table 4.4 shows the level of use of social media in reference services in their library. $18(38.3 \%)$ respondents affirmed that the rate of using social media to reference services in their library was low, $13(27.7 \%)$ respondents affirmed that there was moderate, only $10(21.3 \%)$ respondents affirmed that the use was high while $06(12.8 \%)$ respondents affirmed that it was never used at all. Therefore social media use by librarians for reference services in academic libraries in Nigeria is very low when the number of respondents that indicated none use, low use and even the 15 persons who did not answer the questions are put together. Table 4.4 still affirms the low use of social media platforms for reference services in academic libraries in Nigeria. 
Table 4.5: Issues to the use of Social Media in the Library

\begin{tabular}{|c|c|c|c|c|c|c|c|c|c|}
\hline \multirow{2}{*}{\begin{tabular}{|l|} 
Statement \\
1. Lack of awareness of \\
the various kinds of \\
social media and their \\
application to \\
reference services \\
\end{tabular}} & \multicolumn{2}{|c|}{ Strongly Agree } & \multicolumn{2}{|c|}{ Agree } & \multicolumn{2}{|c|}{ Disagree } & \multicolumn{2}{|c|}{$\begin{array}{l}\text { Strongly } \\
\text { Disagree }\end{array}$} & Total \\
\hline & 18 & $34.6 \%$ & 21 & $40.3 \%$ & & $13.5 \%$ & 06 & $11.5 \%$ & 52 (100\%) \\
\hline $\begin{array}{l}\text { 2. Lack of librarians } \\
\text { training on the } \\
\text { application of the } \\
\text { various kinds of mass } \\
\text { media to reference } \\
\text { services }\end{array}$ & 17 & $32.1 \%$ & 27 & $50.9 \%$ & & $15.1 \%$ & 01 & $1.9 \%$ & 53 (100\%) \\
\hline $\begin{array}{l}\text { 3. Dogmatism on the } \\
\text { part of librarians }\end{array}$ & 07 & $32.1 \%$ & & $50.9 \%$ & 08 & $15.1 \%$ & 01 & $1.9 \%$ & $50 \quad(100 \%)$ \\
\hline $\begin{array}{l}\text { 4. There is } \\
\text { infrastructural problem }\end{array}$ & 16 & $29.6 \%$ & & $57.4 \%$ & 06 & $11.1 \%$ & 01 & $1.9 \%$ & $54 \quad(100 \%)$ \\
\hline $\begin{array}{l}\text { 5.Technical support is a } \\
\text { challenge }\end{array}$ & 18 & $35.3 \%$ & 26 & $51 \%$ & 06 & $11.8 \%$ & 01 & $2 \%$ & $51 \quad(100 \%)$ \\
\hline $\begin{array}{l}\text { 6. There is a security } \\
\text { issue }\end{array}$ & 08 & $15.4 \%$ & 25 & $48.1 \%$ & 16 & $30.8 \% \%$ & 03 & $5.8 \%$ & $52(100 \%)$ \\
\hline $\begin{array}{l}\text { 7. Technophobia is a } \\
\text { limitation }\end{array}$ & 10 & $20.4 \%$ & 20 & $40.8 \%$ & 17 & $34.7 \%$ & 02 & $4.1 \%$ & $49 \quad(100 \%)$ \\
\hline $\begin{array}{l}\text { 8. Lack of access to the } \\
\text { internet }\end{array}$ & 17 & $31.5 \%$ & 22 & $40.7 \%$ & 10 & $18.5 \%$ & 05 & $9.3 \%$ & $54 \quad(100 \%)$ \\
\hline $\begin{array}{l}\text { 9. There is inadequate } \\
\text { user's education }\end{array}$ & 12 & $23.1 \%$ & 27 & $51.9 \%$ & 11 & $21.2 \%$ & 02 & $3.8 \%$ & $52(100 \%)$ \\
\hline 10. Inadequate funding & 21 & $39.6 \%$ & 26 & $49.1 \%$ & 05 & $9.4 \%$ & 01 & $1.9 \%$ & $53 \quad(100 \%)$ \\
\hline
\end{tabular}

table 4.5 shows the constraint to the use of social media in the library. Item 1 on the table shows that $39(74.9 \%)$ respondents agreed that lack of awareness of the various kinds of social media and their application to reference services while $13(25.1 \%)$ respondent disagreed. Item 2 shows that 44(83\%) respondents agreed that lack of librarians training on the application of the various kinds of mass media to reference service while $9(17 \%)$ respondents disagreed. Item 3 on the table shows that 32 (64\%) respondents agreed that dogmatism on the part of the librarians is a constraint to the use of social media in the library while $18(36 \%)$ respondents disagreed. Item 4 shows that $47(87 \%)$ respondent agreed that infrastructural problem is a constraint to the use of social media in the library while $07(13 \%)$ respondents disagreed. Item 5 shows that $44(86.3 \%)$ respondents agreed that technical support is a challenge to the use of social media in the library while 07(13.7\%) respondents disagreed. Item 6 shows that $33(63.5 \%)$ respondents agreed that security issue is a constraint to the use of social media in the library while $19(36.5 \%)$ disagreed. Item 7 shows that $30(61.2 \%)$ respondents agreed that technophobia is a limitation to the use of social media in the library while $19(38.8 \%)$ respondents disagreed. Item 8 shows that 39(72.2\%) respondents agreed that lack of access to the internet is a constraint to the use of social media in the library while $15(27.8 \%)$ respondent disagreed. Item 9 shows that 39(75\%) respondents agreed that inadequate user's education is a constraint to the use of social media in the library while $13(25 \%)$ respondents disagreed. Item 10 shows that $47(88.7 \%)$ respondents agreed that inadequate funding is a constraint to the use of social media in the library while $06(11.3 \%)$ respondents disagreed. 
Table 4.6: Suggestions on Solution to enhance the use of Social Media for Reference Services

\begin{tabular}{|c|c|c|c|c|c|c|c|c|c|}
\hline \multirow{2}{*}{$\begin{array}{l}\text { Statement } \\
\text { 1. Awareness through } \\
\text { seminars/flyers and } \\
\text { brochures }\end{array}$} & \multicolumn{2}{|c|}{ Strongly Agree } & \multicolumn{2}{|c|}{ Agree } & \multicolumn{2}{|c|}{ Disagree } & \multicolumn{2}{|c|}{$\begin{array}{c}\text { Strongly } \\
\text { Disagree }\end{array}$} & Total \\
\hline & & $58 \%$ & 21 & $42 \%$ & 0 & $0 \%$ & 0 & $0 \%$ & $50 \quad(100 \%)$ \\
\hline $\begin{array}{l}\text { 2.Workshops/training } \\
\text { for librarians on the } \\
\text { use of mass media for } \\
\text { reference services }\end{array}$ & 36 & $66.7 \%$ & 18 & $33.3 \%$ & 0 & $0 \%$ & 0 & $0 \%$ & $54 \quad(100 \%)$ \\
\hline $\begin{array}{l}\text { 3.Attitudinal change on } \\
\text { the part of librarians }\end{array}$ & 24 & $43.6 \%$ & & $50.9 \%$ & 03 & $5.5 \%$ & 0 & $0 \%$ & $\begin{array}{ll}55 & (100 \%)\end{array}$ \\
\hline $\begin{array}{l}\text { 4. Provision of } \\
\text { appropriate and } \\
\text { adequate } \\
\text { infrastructure/internet } \\
\text { facilities }\end{array}$ & 35 & $64.8 \%$ & & $35.2 \%$ & 0 & $0 \%$ & 0 & $0 \%$ & $54 \quad(100 \%)$ \\
\hline $\begin{array}{l}\text { 5. Advocacy through } \\
\text { interpersonal } \\
\text { communication within } \\
\text { the academic } \\
\text { community }\end{array}$ & 19 & $35.8 \%$ & & $60.4 \%$ & 02 & $3.8 \%$ & 0 & $0 \%$ & $53 \quad(100 \%)$ \\
\hline $\begin{array}{l}\text { 6.Workshop/training } \\
\text { on use of mass media in } \\
\text { reference services and } \\
\text { faculties }\end{array}$ & 25 & $46.3 \%$ & & $51.9 \%$ & 01 & $1.9 \% \%$ & 0 & $0 \%$ & $54 \quad(100 \%)$ \\
\hline 7. User's enlightenment & 26 & $48.1 \%$ & 28 & $51.9 \%$ & 0 & $0 \%$ & 0 & $0 \%$ & $54 \quad(100 \%)$ \\
\hline 8. Adequate funding & 34 & $63 \%$ & 19 & $35.2 \%$ & 01 & $1.8 \%$ & 0 & $0 \%$ & $54 \quad(100 \%)$ \\
\hline
\end{tabular}

The above table 4.6 shows data on suggestions on solution to enhance the use of social media for reference services. Item 1 on the table shows that $50(100 \%)$ of those that responded to the question agreed that awareness through seminars/flyers and brochure are solution to enhance the use of social media for reference services while none of the respondents disagreed. Item 2 on the table shows that $54(100 \%)$ respondents agreed that workshops/training for librarians on the use of mass media for reference service is a solution while none of the respondent disagreed. Item 3 shows that 52(94.5\%) respondents agreed that attitudinal change on the part of librarians is a solution to enhance the use of social media for reference service while only $03(5.5 \%)$ respondents disagreed. Item 4 shows that $54(100 \%)$ of the respondents agreed that provision of appropriate infrastructure will enhance the use of social media for reference services while none of the respondents disagreed. Item 5 ascertains that 51(96.2\%) respondents agreed that advocacy through interpersonal communication within the academic community will enhance the use of social media for reference services while 02(3.8\%) respondents disagreed. Item 6 shows that 53(98.2\%) respondents agreed that workshop/training on the use of mass media in reference services will enhance the use of social media for reference services while 01(1.9\%) respondent disagreed. Item 7 shows that $54(100 \%)$ respondents agreed that user's education enlightenment will enhance the use of social media for reference service while none of the respondents disagreed. Item 8 shows that $53(98.2 \%)$ respondents agreed that adequate funding will enhance the use of social media for reference services while 1(1.8\%) respondent disagreed.

\section{DISCUSSIONS}

From the findings, majority of the academic library personnel in Nigeria are quite familiar with and do make use of different kinds of social media. The social media platforms being used by the academic library personnel are Facebook, Blogs, linkedin, MySpace, Youtube, flicker, library 
thing, Whatsap and Twitter, with Facebook being the most preferred site, seconded by Whatsap. Despite the high use of the various kinds of social media by academic libraries' personnel in Nigeria, the application of the media for reference services in Nigerian academic libraries is quite low. Though most of the academic library personnel in Nigeria regularly make use of social media platforms, but they do so for reasons order than reference services. Such reasons include interaction with friends, chatting, games, looks and layout and for business networking. It is acceptable for the library personnel to utilise these platforms for personal interactions, but it is also imperative that the core of their profession which is to attend to the library users should be given utmost priority when using these platforms during the working hours.

The findings identified various kinds of problems inhibiting the use of social media by academic library personnel in Nigeria. Such impediments include: Lack of awareness on the various kinds of social media and their application to reference services, dogmatism on the part of some librarians and library personnel (inability to conform/adapt to changes), infrastructural and technological challenges amongst others. Furthermore, there are non regular trainings to enhance and upgrade the library personnel on the emerging technologies and how to apply them to reference services delivery and other aspects of librarianship. Even where such trainings exist, quite a few staff is usually granted approval for sponsorship due to limited library fund allocation. Also some librarians are still dogmatic in the manner they manage the library, including their approach to reference services, they find it difficult to accommodate the changes and innovation ICT is bringing to librarianship. All these coupled with inadequate infrastructure and technical issues are hindering the full integration of social media in reference services in Nigerian academic libraries.

To salvage the situation, the study advocated for the following: Positive attitudinal change on the part of librarians towards the use of technology in the management of libraries; and awareness on the emerging technologies through seminars/flyers and brochure. Also workshops/training for librarians on the use of social media for reference services, provision of appropriate and adequate infrastructure, internet facilities, and advocacy through interpersonal communication within the academic community, user's enlightenment and adequate funding are very imperative.

\section{CONCLUSION}

Academic libraries' personnel in Nigeria have embraced the regular use of social media, but the application of these media in reference services is quite low. To achieve maximum impact of ICT and full integration of the social media in the area of reference services in Nigeria, there is need for regular trainings for the library personnel on the emerging technologies, their relevance to the profession and how to apply them for reference services and other aspects of librarianship.

\section{References}

Achebe N (2012). Current trends and challenges in reference information services in Nigerian libraries. In: Daniel JO, Ifidon EI and Okegbola T (eds) Trends In Library \& information Science in Nigeria: festschrift in honour of Prof. Sam E. Ifidon. Lagos: Elis Assocates.

Adomi EE (2007). Foundations of reference services. Warri: Goddick publisher.

Aichner, T. and Jacob, F. (2015). "Measuring the Degree of Corporate Social Media Use". International Journal of Market Research 57 (2): 257-275. 
Amina, Bakporhonor Blessing (2015). Challenges Librarians Encounter in the use of Social Medial for Promoting Library and Information Resources and Services in University Libraries in South-South, Nigeria. International Journal of Humanities and Social Science Vol. 5, No. 6; 2015.

Andrea Dickson Robert P. Holley, (2010),"Social networking in academic libraries: the possibilities and the concerns", New Library World, Vol. 111 Iss 11/12 pp. 468 - 479 Permanent link to this document: http://dx.doi.org/10.1108/03074801011094840

Boxen, J. (2008), “Library 2.0: a review of the literature”, The Reference Librarian, Vol. 49 No. 1, pp. 21-34.

Cardina, Christen and Donald Wicks. 2004. "The Changing Roles of Academic Reference Librarians over a TenYear Period.” Reference and User Services Quarterly 44 (2): 133-142

Carlota Lorenzo-Romero, María-del-Carmen Alarcón-del-Amo, and Efthymios Constantinides (2014) Determinants of Use of Social Media Tools in Retailing Sector Journal of Theoretical and Applied Electronic Commerce Research VOL 9 ISSUE 1 available at www.jtaer.com DOI: 10.4067/S0718-18762014000100005

Craig Gibson and Meris Mandernach (2013) Reference Service at an Inflection Point: Transformations in Academic Libraries ACRLIndianapolis, IN

Farkas, M. (2007a), “Going where patrons are”, American Libraries, Vol. 38 No. 4, p. 27.

Farkas, M. (2007b), "Your stuff, their space”, American Libraries, Vol. 38 No. 11, p. 36

2.^ Jump up Kietzmann, Jan; Kristopher Hermkens (2011). "Social media? Get serious! Understanding the functional building blocks of social media". Business Horizons 54: 241-251. doi:10.1016/j.bushor.2011.01.005.

4.Jump up ^ Pavlik \& MacIntoch, John and Shawn (2015). Converging Media 4th Edition. New York, NY: Oxford University Press. p. 189. ISBN 978-0-19-934230-3.

5.Jump up ^ Murthy, Dhiraj (2013). Twitter: Social Communication in the Twitter Age. Cambridge: Polity. pp. 7-8. ISBN 978-0-7456-6510-8.

6.Jump up ^ "State of the media: The social media report 2012". Featured Insights, Global, Media + Entertainment. Nielsen. Retrieved 9 December 2012.

7.Jump up ^ Tang, Qian; Gu, Bin; Whinston, Andrew B. (2012). "Content Contribution for Revenue Sharing and Reputation in Social Media: A Dynamic Structural Model". Journal of Management Information Systems 29: 41-75. doi:10.2753/mis0742-1222290203.

Kaplan Andreas M., Haenlein Michael (2010). "Users of the world, unite! The challenges and opportunities of social media". Business Horizons 53 (1). p. 61. doi:10.1016/j.bushor.2009.09.003.

Kim, Y.M., \& Abbas, J. (2010). Adoption of Library 2.0 functionalities by academic libraries and users: A knowledge management perspective. The Journal of Academic Librarianship, 36(3), 211-218.

Kousha K, Thelwall M (2008) Assessing the impact of disciplinary research on teaching: An automatic analysis of online syllabuses. Journal of the American Society for Information Science and Technology 59: 2060-2069.

Martin, Pamela. 2009. "Societal Transformation and Reference Services in the Academic Library: Theoretical Foundations for Re-envisioning Reference." Library Philosophy and Practice May. Accessed February 13, 2013. http://unllib.unl.edu/LPP/pamelamartin.htm.

Mathews, B. (2007a), “Moving beyond the reference desk: being where users need us”, The Reference Librarian, Vol. 48 No. 2, pp. 9-13. Mathews, B. (2007b), “Online social networking”, in Courtney, N. (Ed.), Library 2.0 and beyond: Innovative Technologies and Tomorrow's User, Libraries Unlimited, Westport, CT, pp. 75-90.

Thelwall M, Kousha K (2008) Online presentations as a source of scientific impact?: An analysis of PowerPoint files citing academic journals. Journal of the American Society for Information Science and Technology 59: 805815.

Tyckoson, David A. 2012. "Issues and Trends in the Management of Reference Services: A Historical Perspective." Journal of Library Administration 52 (6-7): 581-600.

Wang, Hanrong, Yingqi Tang, and Carley Knight. 2010. “Contemporary Development of Academic Reference Librarianship in the United States: a 44-year Content Analysis.” The Journal of Academic Librarianship 36 (6): 489-494. 